\title{
Synthesis, Characterization, in vitro Antimicrobial, and Anthelmintic Evaluations of N-(4, 6-dimethylpyrimidin-2-yl)-4- ((2-hydroxynaphthalen-1-yl) diazenyl) Benzene Sulfonamide and Its Metal (II) Complexes
}

\author{
Jagdish Badgujar ${ }^{1}$, Dhananjay More ${ }^{1}$, Jyotsna Meshram²* \\ ${ }^{1}$ School of Chemical Sciences, North Maharashtra University, Jalgaon 425001, India \\ ${ }^{2}$ Department of Chemistry, Rashtrasant Tukadoji Maharaj Nagpur University, Nagpur 440033, India \\ Email: drjsmeshram@gmail.com
}

\begin{abstract}
As a part of systematic investigation of biologically active compound, new azo dye ligand $\mathrm{N}-(4,6$-dimethylpyrimidin-2-yl)-4-((2-hydroxynaphthalen-1-yl) diazenyl) benzene sulfonamide has been synthesized by diazotization of 4-amino-N-(4, 6-dimethylpyrimidin-2-yl) benzenesulfonamide and coupled with coupling compound, naphthalen-2-ol. A new series of $\mathrm{Ni}$ (II), $\mathrm{Cu}$ (II), and $\mathrm{Zn}$ (II) complexes derived from this azo dye ligand (L) were synthesized. The structures of the ligand and metal complexes were confirmed by spectroscopic studies (elemental analysis, IR, 1H NMR and mass spectra). The azo dye and its complexes have been screened for their in vitro antimicrobial activities against some bacterial stains and fungal strains by disc diffusion method. The results showed that, the presence of metal causes more inhibition. The anthelmentic activity of the ligand and its complexes against adult Indian earthworms, Pheretima postuma are also investigated.
\end{abstract}

Keywords: Azo dye, sulfonamide, metal complexes, antimicrobial activity, anthelmentic activity.

\section{Introduction}

In the last few years, the emergence of resistant human pathogens has been a major issue in antimicrobial therapy [1-2], encouraging efforts to develop novel drugs. Metal complexes were found to be particularly useful in this matter, extending the landscape of drug design and enabling novel mechanisms of action. Azo dyes are good bidentate [3-4] as well as tridentate [5] chelating agents that can form stable complexes with transitional and non transitional metal ions because of the presence of azo $(-\mathrm{N}=\mathrm{N}-)$ group i.e., lone pair of orbitals containing two electrons on nitrogen atom [6-9]. Hence, much attention has been focused on their special role as coordinating ligands in main group and transition metal coordination chemistry [10-13].

Nowadays, the development of new heterocyclic based azo dye derivatives is becoming the significant attraction of medicinal chemist [14-15] because several studies have been put forward by researchers regarding the biological activities of azo dye, including their herbicidal, anti-inflammatory, antimicrobial, antiulcer drug, antifungal, antibacterial, antitubercular, antibiotics [16-18] activities.

The growing interest in transition metal complexes containing azo dyes with antibiotics is derived from their functions and well-established chemical in biological systems as well as their pharmaceutical and catalytic applications [19-21]. Sulfonamides are the antibiotics [22] which are mainly used for treatment or prevention of many kinds of bacterial inflammations due to their ability to inhibit the bacterial growth in wounds or infected organs without appreciable toxicity to normal tissues [23].

Having these all in our mind, we report herein the synthesis, characterization and biological screening of metal complexes of azo dye ligand derived from the coupling of 4-amino-N-(4, 6-dimethylpyrimidin-2yl) benzenesulfonamide with naphthalen-2-ol.

\section{Experimental}

\subsection{Chemicals and Instrumentations}


All compounds used in the present study were of pure grade available from Aldrich or Sigma. The solvents used for the synthesis and spectral study were spectroscopic grade from Aldrich. Melting points of the synthesized compounds were taken by one end open capillary tubes melting point apparatus and are uncorrected. The structural determinations were carried out by using elemental analysis, FT-IR, 1H NMR, MS spectroscopic techniques. Elemental analysis was carried out on a FLASH EA 1112 series. FT-IR spectra were recorded on the Perkin Elmer spectrum one Ltd., Singapore Spectrophotometer, by uniformly mixing the sample with $\mathrm{KBr} .{ }^{1} \mathrm{H}$ NMR spectrum was recorded in DMSO as a solvent with BRUKER ADVANCEII 400 Spectrometer with tetramethylsilane (TMS) as an internal reference standard. Mass spectra were recorded under ESI (+ve) mode, on WATERS, Q-TOF MICROMASS.

\subsection{Synthesis of the Ligand [24]}

\section{Step I: Diazotization}

A mixture of 4-amino-N-(4, 6-dimethylpyrimidin-2-yl) benzenesulfonamide (10 mmol) and conc $\mathrm{HCl}$ has synthesized and stirred until a clear solution was obtained. $\mathrm{HCl}$ was stirred until a clear solution was obtained. This solution was cooled to $0-5^{\circ} \mathrm{C}$ and a solution of sodium nitrite in $10 \mathrm{ml}$ water was then added dropwise with maintaining the temperature below $5^{\circ} \mathrm{C}$. The resulting mixture was stirred for an additional $30 \mathrm{~min}$ in an ice bath and was then buffered ( $\mathrm{pH} 5.0$ ) with solid sodium acetate trihydrate.

\section{Step II: Coupling}

Corresponding naphthalen-2-ol $(10 \mathrm{mmol})$ was dissolved in $30 \mathrm{ml} 10 \% \mathrm{NaOH}$, and cooled to $0-5^{\circ} \mathrm{C}$ in an ice bath. This solution was then gradually added to the cooled diazonium salt solution and the resulting mixture was stirred at $0-5^{\circ} \mathrm{C}$ for $1 \mathrm{~h}$. The resulting crude precipitate was filtered, washed several times with cold water and recrystallized from hot chloroform to yield azo compound (Figure 1).

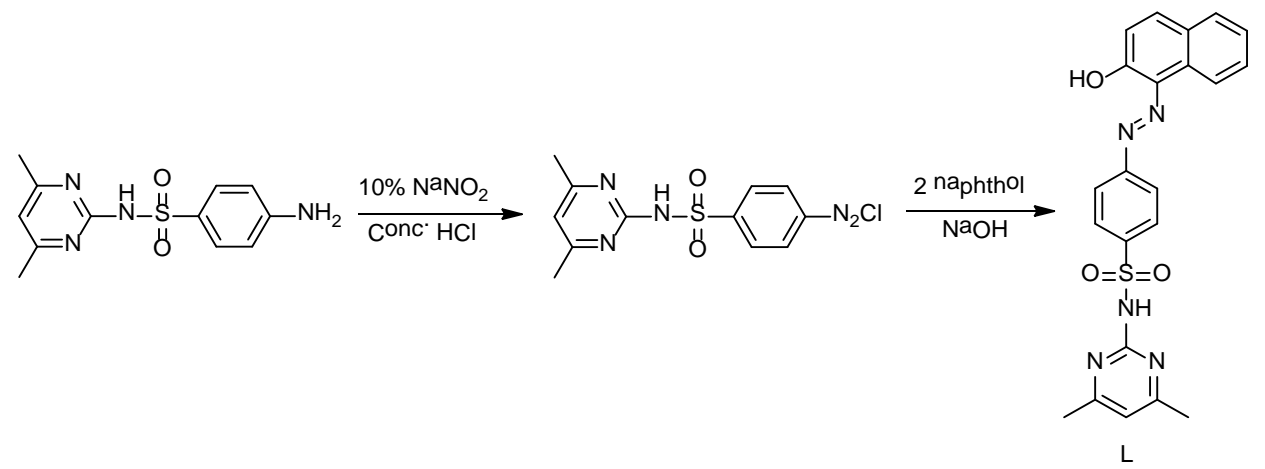

Figure 1. Synthesis of Ligand

Yield: $64 \%$. M.P. $184^{\circ} \mathrm{C}$

Solubility: DMSO, ethanol, methanol, chloroform, acetonitrile and DMF solvents.

IR of KBr: Umax $/ \mathrm{cm}^{-1}=3342 \mathrm{~cm}^{-1}$ (O-H stretching), $3097 \mathrm{~cm}^{-1}\left(\mathrm{~N}-\mathrm{H}\right.$ stretching), $2993 \mathrm{~cm}^{-1}(\mathrm{C}-\mathrm{H}$ aliphatic, stretching), $1581 \mathrm{~cm}^{-1}\left(\mathrm{C}=\mathrm{C}\right.$ aromatic stretching), $1512 \mathrm{~cm}^{-1}(\mathrm{~N}=\mathrm{N}$ azo, stretching $), 1256 \mathrm{~cm}^{-1}$ (C-O, stretching), $1132 \mathrm{~cm}^{-1}(\mathrm{~S}=\mathrm{O}$ sulfonamide, stretching)

${ }^{1} \mathrm{H}$ NMR (400MHz, CDCl3, TMS, $\mathrm{s}=$ singlet, $\mathrm{d}=$ doublet, $\mathrm{t}=$ triplet, $\mathrm{h}=$ heptet, $\mathrm{m}=$ multiplet): $(\delta, \mathrm{ppm})=2.23\left(\mathrm{~s}, 6 \mathrm{H}, \mathrm{CH}_{3}\right), 15.92(\mathrm{~s}, 1 \mathrm{H},-\mathrm{OH}), 8.17(\mathrm{~s}, 1 \mathrm{H},-\mathrm{NH}), 6.40-8.44(\mathrm{~m}, 11 \mathrm{H}, \mathrm{Ar}-\mathrm{H})$. Mass (TOF MS ES +) for $\mathrm{C}_{22} \mathrm{H}_{19} \mathrm{~N}_{5} \mathrm{O}_{3} \mathrm{~S}(\mathrm{~m} / \mathrm{z}), 434[\mathrm{M}+1]^{+}$.

Anal. Calcd: $\mathrm{C}_{22} \mathrm{H}_{19} \mathrm{~N}_{5} \mathrm{O}_{3} \mathrm{~S}$ : C, 60.96; H, 4.42; N, 16.16. Found: C, 60.72; H, 4.10; N, 16.40 .

\subsection{Synthesis of Complexes[25]}

An ethanolic solution of the Azo dye ligand (1.0 equiv.) was added gradually with stirring to the metal (II) chloride ( 0.5 equiv.) and sodium acetate (1.0 equiv.) at room temperature for $4 \mathrm{~h}$. The mixture was poured into cold $\mathrm{NaCl}$ solution and then kept for $30 \mathrm{~min}$ in an ice bath. The crude precipitate was isolated by filtration, washed several times with water (Figure 2). 


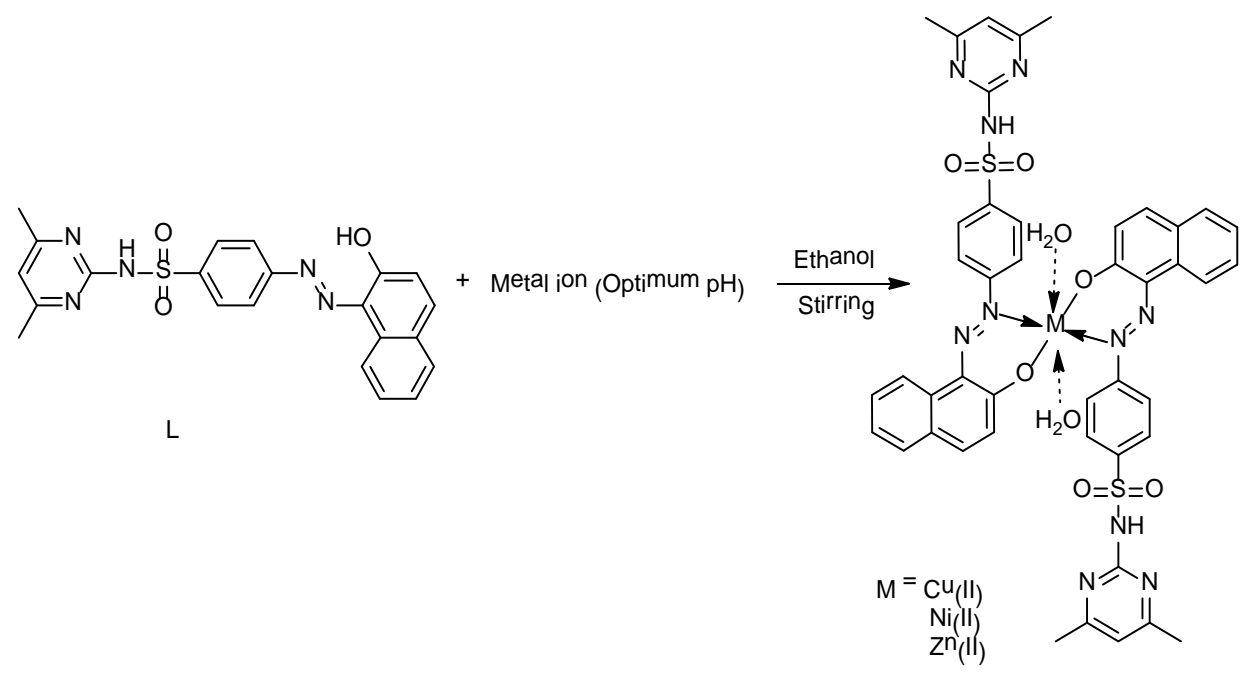

Figure 2. Proposed structure of metal (II) complexes

\section{Synthesis of $L$ - Ni complex}

Yield: $58 \%$. M.P. $262{ }^{\circ} \mathrm{C}$.

Solubility: DMSO, acetonitrile and DMF solvents.

IR of KBr: Umax $/ \mathrm{cm}^{-1}=3116 \mathrm{~cm}^{-1}(\mathrm{~N}-\mathrm{H}$ stretching $), 1498 \mathrm{~cm}^{-1}(\mathrm{~N}=\mathrm{N}$ azo, stretching $), 1583 \mathrm{~cm}^{-1}$ ( $\mathrm{C}=\mathrm{C}$ aromatic stretching), $1368 \mathrm{~cm}^{-1}$ (C-O, stretching), $1140 \mathrm{~cm}^{-1}$ ( $\mathrm{S}=\mathrm{O}$ sulfonamide, stretching), $419 \mathrm{~cm}^{-1}$ (Ni-O stretching), $629 \mathrm{~cm}^{-1}$ (Ni-N stretching), $847 \mathrm{~cm}^{-1}\left(\mathrm{Ni}-\mathrm{OH}_{2}\right)$.

MS (TOF MS ES+) for $\mathrm{C}_{44} \mathrm{H}_{40} \mathrm{NiN}_{10} \mathrm{O}_{8} \mathrm{~S}_{2}(\mathrm{~m} / \mathrm{z}), 960[\mathrm{M}]^{+}$

Anal. Calcd: $\mathrm{C}_{44} \mathrm{H}_{40} \mathrm{~N}_{10} \mathrm{NiO}_{8} \mathrm{~S}_{2}$ : C, 55.07; H, 4.20; N, 14.60. Found C, 54.79; H, 4.33; N, 14.43.

\section{Synthesis of L-Cu complex}

Yield: $65 \%$. M.P. $278{ }^{\circ} \mathrm{C}$.

Solubility: DMSO, acetonitrile and DMF solvents.

IR of $\mathrm{KBr}$ : Umax $/ \mathrm{cm}^{-1}=3114 \mathrm{~cm}^{-1}$ (N-H stretching), $2802 \mathrm{~cm}^{-1}\left(\mathrm{C}-\mathrm{H}\right.$ aliphatic stretching), $1496 \mathrm{~cm}^{-1}$ $\left(\mathrm{N}=\mathrm{N}\right.$ azo, stretching), $1597 \mathrm{~cm}^{-1}\left(\mathrm{C}=\mathrm{C}\right.$ aromatic stretching), $1342 \mathrm{~cm}^{-1}$ (C-O, stretching), 1144 $\mathrm{cm}^{-1}$ $\left(\mathrm{S}=\mathrm{O}\right.$ sulfonamide, stretching), $449 \mathrm{~cm}^{-1}$ (Cu-O stretching), $588 \mathrm{~cm}^{-1}$ (Cu-N stretching), $868 \mathrm{~cm}^{-1}\left(\mathrm{Cu}^{-}\right.$ $\left.\mathrm{OH}_{2}\right)$

MS (TOF MS ES+) for $\mathrm{C}_{44} \mathrm{H}_{40} \mathrm{CuN}_{10} \mathrm{O}_{2} \mathrm{~S}_{2}(\mathrm{~m} / \mathrm{z}), 965[\mathrm{M}]^{+}$

Anal. Calcd: $\mathrm{C}_{44} \mathrm{H}_{40} \mathrm{CuN}_{10} \mathrm{O}_{8} \mathrm{~S}_{2}$ : C, 54.79; H, 4.18; N, 14.52. Found: C, 54.09; H, 4.47; N, 14.29.

\section{Synthesis of L- Zn (II) complex}

Yield: $71 \%$. M.P. $290{ }^{\circ} \mathrm{C}$.

Solubility: DMSO, acetonitrile and DMF solvents.

IR of $\mathrm{KBr}$ : Umax $/ \mathrm{cm}^{-1}=3110 \mathrm{~cm}^{-1}(\mathrm{~N}-\mathrm{H}$ stretching $), 2801 \mathrm{~cm}^{-1}(\mathrm{C}-\mathrm{H}$ aliphatic stretching $), 1493 \mathrm{~cm}^{-1}$ ( $\mathrm{N}=\mathrm{N}$ azo, stretching), $1592 \mathrm{~cm}^{-1}$ ( $\mathrm{C}=\mathrm{C}$ aromatic stretching), $1145 \mathrm{~cm}^{-1}$ ( $\mathrm{S}=\mathrm{O}$ sulfonamide, stretching), $440 \mathrm{~cm}^{-1}$ (Zn-O stretching), $579 \mathrm{~cm}^{-1}$ (Zn-N stretching), $866 \mathrm{~cm}^{-1}\left(\mathrm{Zn}^{-} \mathrm{OH}_{2}\right)$.

MS (TOF MS ES+) for $\mathrm{C}_{44} \mathrm{H}_{40} \mathrm{ZnN}_{10} \mathrm{O}_{8} \mathrm{~S}_{2}(\mathrm{~m} / \mathrm{z}), 967[\mathrm{M}]^{+}$

Anal. Calcd: $\mathrm{C}_{44} \mathrm{H}_{40} \mathrm{~N}_{10} \mathrm{O}_{8} \mathrm{~S}_{2} \mathrm{Zn}$ : C, 54.69; H, 4.17; N, 14.49. Found: C, 54.90; H, 4.04; N, 14.63.

\subsection{Antimicrobial Study[26]}

The biological activities of synthesized azo dye and their metal complexes have been studied for their antibacterial and antifungal activities by well diffusion method. The stock solutions (0.001 mol) were prepared by dissolving all the compounds in DMSO, and the solutions were serially diluted to find the minimum inhibitory concentration (MIC) values $(\mu \mathrm{gmL}-1)$. Four bacterial stains (Staphylococcus aureus, Escherichia coli, Pseudomonas aeruginosa, and Bacillus subtilis) were incubated for 24 h at 37 ${ }^{\circ} \mathrm{C}$, and fungal stains (Aspergillus niger, Candida albicans, and Rhizoctonia bataticola) were incubated for $48 \mathrm{~h}$ at $37{ }^{\circ} \mathrm{C}$. Standard antibacterial Streptomycin and antifungal drug Nystatin were used for comparison under similar conditions. Antimicrobial activity studies were performed in triplicate, and the 
average was taken as the final reading.

\subsection{Anthelmintic Activity[27]}

The Anthelmintic activity was carried out on adult Indian earthworms, Pheretima postuma. The worms were collected from local moist place and prior assay: the worms were washed with normal saline so as to remove all fecal matter. They were divided into 06 groups of 6 worms each. Distilled water was used as control while Albendazole $(10 \mathrm{mg} / \mathrm{ml})$ was used as reference standard for this study. Three different concentrations $5 \mathrm{mg} / \mathrm{ml}, 10 \mathrm{mg} / \mathrm{ml}$ and $15 \mathrm{mg} / \mathrm{ml}$ for the ligand with complex and standard drug solution of albendazole were freshly prepared and poured into Petri dishes. Worms were then introduced into the Petri dishes and observations were made for the time taken for paralysis and death of worms. Paralysis was said to occur when the worms do not revive even in normal saline. Death was confirmed when the worms showed zero movement when shaken vigorously or when dipped in warm water $\left(50^{\circ} \mathrm{C}\right)$ followed with fading away of their body color. The results obtained are expressed as mean \pm S.E.M. (standard error of mean). Statistical differences were carried out using the Analysis of Variance (ANOVA) and was considered significant when $\mathrm{P}<0.05$. (Table 3 ).

\section{Results and Discussion}

Table 1 shows the molecular formula, molecular weight, melting points, percent yield and Rf values of all the synthesized compounds.

Table 1. Elemental analysis data and physical properties of the ligand and its metal complexes.

\begin{tabular}{|c|c|c|c|c|c|c|c|c|c|}
\hline \multirow[t]{2}{*}{$\begin{array}{l}\text { Comp. } \\
\text { code }\end{array}$} & \multirow[t]{2}{*}{$\begin{array}{l}\text { Mole. } \\
\text { formula }\end{array}$} & \multirow{2}{*}{$\begin{array}{c}\text { M.W. } \\
\text { (g mol- } \\
1 \text { ) }\end{array}$} & \multirow[t]{2}{*}{ Color } & \multirow[t]{2}{*}{$\begin{array}{l}\text { M.P. } \\
\left({ }^{\circ} \mathrm{C}\right)\end{array}$} & \multirow[t]{2}{*}{$\begin{array}{l}\text { Yield } \\
(\%)\end{array}$} & \multirow[t]{2}{*}{$\begin{array}{c}\mathrm{Rf}^{\mathrm{a}} \\
\text { Value }\end{array}$} & \multicolumn{3}{|c|}{$\begin{array}{l}\text { Analysis found } \\
\text { (calculated \%) }\end{array}$} \\
\hline & & & & & & & $\% \mathrm{C}$ & $\% \mathrm{H}$ & $\% \mathrm{~N}$ \\
\hline $\mathbf{L}$ & $\mathrm{C}_{22} \mathrm{H}_{19} \mathrm{~N}_{5} \mathrm{O}_{3} \mathrm{~S}$ & 433 & Orange & 184 & 68.59 & 0.66 & $\begin{array}{c}60.72 \\
(60.96)\end{array}$ & $\begin{array}{c}4.10 \\
(4.42)\end{array}$ & $\begin{array}{c}16.40 \\
(16.16)\end{array}$ \\
\hline $\mathrm{Ni}(\mathrm{L})_{2}$ & $\mathrm{C}_{44} \mathrm{H}_{40} \mathrm{~N}_{10} \mathrm{NiO}_{8} \mathrm{~S}_{2}$ & 959 & Brown & 262 & 53.22 & 0.30 & $\begin{array}{c}54.79 \\
(55.07)\end{array}$ & $\begin{array}{c}4.33 \\
(4.20)\end{array}$ & $\begin{array}{c}14.43 \\
(14.60)\end{array}$ \\
\hline $\mathrm{Cu}(\mathrm{L})_{2}$ & $\mathrm{C}_{44} \mathrm{H}_{40} \mathrm{CuN}_{10} \mathrm{O}_{8} \mathrm{~S}_{2}$ & 964 & Brown & 278 & 59.84 & 0.35 & $\begin{array}{c}54.09 \\
(54.79)\end{array}$ & $\begin{array}{c}4.47 \\
(4.18)\end{array}$ & $\begin{array}{c}14.29 \\
(14.52)\end{array}$ \\
\hline $\mathrm{Zn}(\mathrm{L})_{2}$ & $\mathrm{C}_{44} \mathrm{H}_{40} \mathrm{~N}_{10} \mathrm{O}_{8} \mathrm{~S}_{2} \mathrm{Zn}$ & 966 & Orange & 290 & 60.72 & 0.40 & $\begin{array}{c}54.90 \\
(54.69)\end{array}$ & $\begin{array}{c}4.04 \\
(4.17)\end{array}$ & $\begin{array}{c}14.63 \\
(14.49)\end{array}$ \\
\hline
\end{tabular}

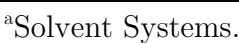

Hexen:Ethyl acetate (4:6): Ligand.

Hexen:Ethyl acetate (1:9): Comps. $\mathrm{Cu}(\mathrm{L})_{2}, \mathrm{Ni}(\mathrm{L})_{2}, \mathrm{Zn}(\mathrm{L})_{2}$

The azo dye ligand was prepared by reacting equimolar amounts of 4-amino-N-(4, 6dimethylpyrimidin-2-yl) benzenesulfonamide 4-amino-N-(4, 6-dimethylpyrimidin-2-yl) benzenesulfonamide and naphthalen-2-ol in ethanol medium. The structures of the ligand and the complexes were established from their elemental analysis, FT- IR, ${ }^{1} \mathrm{H}-\mathrm{NMR}$ spectra, and mass spectroscopy. The complexes are intensely coloured stable solids. The results of the mass analysis of the azo dye and its complexes are in good agreement with those calculated for the suggested formula and agree with a 1: 2 metal to ligand stoichiometry for all the complexes.

\subsection{Elemental Analysis}

The results of elemental analysis of the prepared ligand and its metal complexes along with their physical properties are collected in Table 1. The analytical data of the metal complexes indicated that the complexes have 1:2 (metal: ligand) stoichiometry. Based on the results, the corresponding possible constitutional formulae of the metal complexes were suggested as given in the same tables. The metal 
complexes showed high stability in air when they were left for a long time. They are also insoluble in most organic solvents, except DMF and DMSO.

\subsection{Infrared Spectra}

The structurally significant IR bands for free ligand and its complexes have been reported in Table 2 . In the IR spectrum of HL \& its complexes, a broad band at $3442 \mathrm{~cm}^{-1}$ can be attributed to O-H ${ }^{\cdots \cdots} \mathrm{N}$ intramolecular hydrogen bonding in ligand and its absence in the metal complexes that indicates the deprotonation of phenolic -OH group, thereby showing its coordination to the metal ions. The bands observed at $2800-2950 \mathrm{~cm}^{-1}$ in ligand and complexes suggest for the $\mathrm{C}-\mathrm{H}$ vibrations in compounds. The band of vibration for $\mathrm{SO}_{2}$ of sulfonamide in azo dyes and azo-metal chelates observed around at 1140 $\mathrm{cm}^{-1}$. Absorption bands in the region of $2600-1400 \mathrm{~cm}^{-1}$ show the presence of $>\mathrm{C}-\mathrm{O},>-\mathrm{N}=\mathrm{N}-$ and $>\mathrm{C}=\mathrm{C}$ functional groups. The bands around $1500 \mathrm{~cm}^{-1} \& 1250-1350 \mathrm{~cm}^{-1}$ described the $-\mathrm{N}=\mathrm{N}-$ and phenolic $\mathrm{C}-\mathrm{O}$ vibrations in ligand and complexes respectively. Absorption in the $1400-1000 \mathrm{~cm}^{-1}$ region involves other bands such as the aromatic $\mathrm{C}-\mathrm{H}$ in plane deformation vibration, $\mathrm{C}-\mathrm{N}$ stretching vibration and C-C stretching vibration. The bathochromic shifts at the vibration spectra of the azo-metal chelates showed bands between 1325 and $1345 \mathrm{~cm}^{-1}$ where the phenolic C-O stretching vibration of azo dye ligand occur between 1336 and $1343 \mathrm{~cm}^{-1}$. In the absorption region between 1000-400 $\mathrm{cm}^{-1}$ of complexes, new bands were noticed at $860 \mathrm{~cm}^{-1}$ which were assigned as ring def $+v(\mathrm{M}-\mathrm{OH})_{2}$, i.e., coordination of water molecule in azo-metal chelates, new bands around $550 \mathrm{~cm}^{-1}$ which was assigned as $\nu(\mathrm{M}-\mathrm{N})$, while the bands around $450 \mathrm{~cm}^{-1}$ was assigned as $\nu(\mathrm{M}-\mathrm{O})$.

Table 2. Characteristic IR bands of Ligand and its azo-metal chelates as $\mathrm{KBr}$ pellets $\mathrm{cm}^{-1}$

\begin{tabular}{ccccccccc}
\hline Compounds & $-\mathbf{O H}$ & $-\mathbf{N H}$ & $-\mathrm{C}-\mathrm{O}$ & $-\mathbf{N}=\mathbf{N}-$ & $\mathbf{S O}_{2}$ & $\mathbf{M - O}$ & $\mathbf{M}-\mathbf{N}$ & $\mathbf{M - O H}_{2}$ \\
\hline $\mathrm{L}$ & 3342 & 3097 & 1256 & 1512 & 1132 & - & - & - \\
$\mathrm{Ni}(\mathrm{L})_{2}$ & - & 3116 & 1368 & 1498 & 1140 & 419 & 629 & 874 \\
$\mathrm{Cu}(\mathrm{L})_{2}$ & - & 3114 & 1342 & 1496 & 1144 & 449 & 588 & 868 \\
$\mathrm{Zn}(\mathrm{L})_{2}$ & - & 3110 & 1356 & 1493 & 1145 & 440 & 579 & 866 \\
\hline
\end{tabular}

\section{$3.3 \quad{ }^{1} \mathrm{H}$ NMR Spectra}

The ${ }^{1} \mathrm{H}$ NMR spectra show a signal at $15.92 \mathrm{ppm}$ for ligand. This chemical shifts can be attributed to hydrogen bounded $\mathrm{OH}$ proton. It is well known that hydrogen bounded $\mathrm{OH}$ proton resonance appears at lower field than that of $\mathrm{NH}$ proton resonance. Furthermore, the singlet peak at $8.17 \mathrm{ppm}$ is attributed to $\mathrm{NH}$ proton of azo ligand. A characteristic peak of singlet for 6 protons for two $\mathrm{CH}_{3}$ groups at the 2- and 4-positions of 4-amino- $\mathrm{N}-(4, \quad 6$-dimethylpyrimidin-2-yl) benzenesulfonamide 4-amino- $\mathrm{N}-(4, \quad 6$ dimethylpyrimidin-2-yl) benzenesulfonamide ring appears at $2.23 \mathrm{ppm}$. The 11 peaks appearing in between 6.40 - $8.44 \mathrm{ppm}$ are attributed to aromatic ring protons of ligand.

\subsection{Mass Spectra}

The mass spectra of azo dye and its complexes were recorded at room temperature, and they are used to compare their stoichiometry composition.

The molecular ion $[\mathrm{M}+1]$ peak observed at $\mathrm{m} / \mathrm{z} 434(100 \%)$ coincides with the formula weight of $\mathrm{L}$. Whereas the molecular ion [M+2] peak for $\mathrm{Ni}(\mathrm{II}), \mathrm{Cu}(\mathrm{II})$, and $\mathrm{Zn}(\mathrm{II})$ complexes observed at $\mathrm{m} / \mathrm{z}=961$, 966 , and 968 equivalent to its molecular weight confirms the stoichiometric composition of $\mathrm{M}\left[\mathrm{L}_{2}\right] 2\left(\mathrm{H}_{2} \mathrm{O}\right)$ type.

\subsection{Antimicrobial Study}

The antimicrobial activity results (fig.3) reveal that the $\mathrm{Cu}(\mathrm{II})$ and $\mathrm{Zn}(\mathrm{II}$ ) complex shows significant activity against all the tested bacterial strains, and in general the activity order of the synthesized compounds can be represented as $\mathrm{Cu}(\mathrm{II})>\mathrm{Ni}(\mathrm{II})>\mathrm{Zn}(\mathrm{II})>\mathrm{L}$. The higher activity of the metal complexes may be owing to the effect of metal ions on the normal cell membrane [28]. Metal chelates 
stand jointly the polar and nonpolar properties; due to this, they can easily penetrate the cells and tissues. In addition, chelation might increase or suppress the biochemical potential of bioactive organic species. Further, lipophilicity, which controls the rate of entry of molecules into the cell, is personalized by coordination, so the metal complex can become highly active than the free ligand. Consequently, the metal complexes show better antimicrobial activities than the uncoordinated ligand which in fact is in agreement with the literature [29].

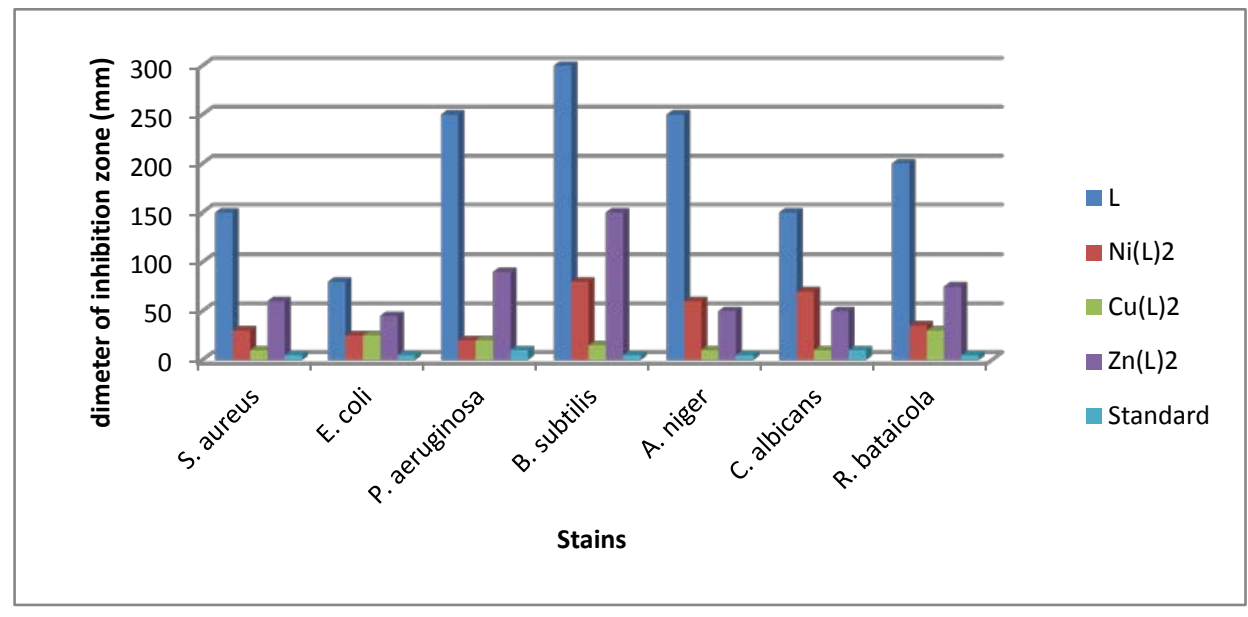

Figure 3. Antimicrobial activity of ligand, their metal (II) complexes evaluated by minimum (MIC inhibitory concentration, $\mu \mathrm{g} / \mathrm{mL})$.

Table 3. Anthelmintic activity

\begin{tabular}{|c|c|c|c|c|c|c|}
\hline \multirow[t]{2}{*}{ Compounds } & \multicolumn{2}{|c|}{$5 \mathrm{mg} / \mathrm{ml}$} & \multicolumn{2}{|c|}{$10 \mathrm{mg} / \mathrm{ml}$} & \multicolumn{2}{|c|}{$15 \mathrm{mg} / \mathrm{ml}$} \\
\hline & $\begin{array}{l}\text { Time taken } \\
\text { for paralysis } \\
\text { (min) }\end{array}$ & $\begin{array}{c}\text { Time taken } \\
\text { for death } \\
(\min )\end{array}$ & $\begin{array}{c}\text { Time taken } \\
\text { for paralysis } \\
\text { (min) }\end{array}$ & $\begin{array}{c}\text { Time taken } \\
\text { for death } \\
(\mathrm{min})\end{array}$ & $\begin{array}{c}\text { Time taken } \\
\text { for paralysis } \\
(\text { min })\end{array}$ & $\begin{array}{c}\text { Time taken } \\
\text { for death } \\
(\min )\end{array}$ \\
\hline Control & - & - & - & - & - & - \\
\hline Albendazole & $72 \pm 0.6$ & $85 \pm 0.2$ & $67 \pm 0.7$ & $80 \pm 0.5$ & $65 \pm 0.6$ & $78 \pm 0.9$ \\
\hline $\mathrm{L}$ & $71 \pm 0.3$ & $83 \pm 0.9$ & $65 \pm 0.9$ & $78 \pm 0.4$ & $60 \pm 0.5$ & $67 \pm 0.3$ \\
\hline $\mathrm{Cu}(\mathrm{L})_{2}$ & $55 \pm 0.5^{*}$ & $67 \pm 0.9$ & $51 \pm 0.6$ & $63 \pm 0.7$ & $50 \pm 0.1$ & $62 \pm 0.8$ \\
\hline $\mathrm{Ni}(\mathrm{L})_{2}$ & $70 \pm 0.9$ & $79 \pm 0.6$ & $59 \pm 0.3$ & $75 \pm 0.3$ & $60 \pm 0.3$ & $64 \pm 04$ \\
\hline $\mathrm{Zn}(\mathrm{L})_{2}$ & $62 \pm 0.7$ & $72 \pm 0.8$ & $57 \pm 1.0$ & $71 \pm 0.8^{*}$ & $54 \pm 0.5$ & $67 \pm 0.4$ \\
\hline
\end{tabular}

Results were given in mean \pm SEM and analyzed by ANOVA $* \mathrm{P}<0.05$ compared to standard drug.

\subsection{Anthelmintic Activity}

Anthelmintic activities of all prototypes were tested in this bioassay at various concentrations of 5, 10, and $15 \mathrm{mg} / \mathrm{ml}$ described in Table 3. Almost all compounds have shown significant activity starting from the $10 \mathrm{mg} / \mathrm{ml}$ for time taken to paralysis and death when compared to the standard drug albendazole. At this concentration, compounds $\mathrm{Cu}(\mathrm{L})_{2}$ and $\mathrm{Zn}(\mathrm{L})_{2}$ exhibited their significant action for time taken to paralysis and death. While at $15 \mathrm{mg} / \mathrm{ml}$, all compounds significantly reduced the paralysis and death time as well. Compounds $\mathrm{Ni}(\mathrm{L})_{2}$ exhibited to some extent more time paralysis and death and which is almost an equipotent action when compared to ligand. However at higher concentration of $15 \mathrm{mg} / \mathrm{ml}$ azo dye ligand and its all metal complexes showed time taken to paralysis and death was significantly reducing. 


\section{Conclusion}

$\mathrm{Ni}$ (II) $\mathrm{Cu}$ (II) and Zn (II) complexes of azo dye (L) have been synthesized and characterized by spectral methods. The data indicated that ligand acts as bidentate which coordinates to metal through phenolic oxygen and nitrogen of the azo group. In vitro antimicrobial screenings show that $\mathrm{Cu}(\mathrm{L})_{2}$ is highly active against the all bacterial and fungal strains used in this investigation as compared to ligand and other complexes. The ligand exhibits good anthelmentic activity and highly increases upon complexation with $\mathrm{Cu}$ (II) metal, whereas with other two metals, it shows significant activity when compared to the standard drug albendazole.

Acknowledgements: One of the author gratefully acknowledge financial support from the RFSMS (Research Fellowships in Science for Meritorious Students) F. 25- 1/2014-15 (BSR/7-136/2007(BSR), dated $13^{\text {th }}$ March, 2015).

\section{References}

1. Stuart B. Levy, "Factors impacting on the problem of antibiotic resistance," Journal of Antimicrobial Chemotherapy, vol.49, pp. 25-30, 2002.

2. Bonnie M. Marshall and Stuart B. Levy, "Food Animals and Antimicrobials: Impacts on Human Health," Clinical Microbiology Reviews, vol.24. no.4, pp. 718-733, 2011.

3. Walaa H. Mahmoud, M. M. Omar, Fatma N. Sayed, "Synthesis, spectral characterization, thermal, anticancer and antimicrobial studies of bidentate azo dye metal complexes," J Therm Anal Calorim, vol. 124, pp. 1071-1089, 2016.

4. Bipin Bihari Mahapatra, Ramani Ranjan Mishra, Ashish Kumar Sarangi, "Synthesis, Spectral, Thermogravimetric, XRD, Molecular Modelling and Potential Antibacterial Studies of Dimeric Complexes with Bis Bidentate ON-NO Donor Azo Dye Ligands," Journal of Chemistry, vol. 2013, Article ID 653540.

5. Mohamed Gaber, Yusif S. El-Sayed, Kamal El-Baradie, Rowaida M. Fahmy, "Cu(II) complexes of monobasic bior tridentate (NO, NNO) azo dye ligands: Synthesis, characterization, and interaction with Cu-nanoparticles," Journal of Molecular Structure, vol.1032, pp. 185-194, 2013.

6. Pravin S. Jogi, Jyotsna Meshram, Javed Sheikh, Taibi Ben Hadda, "Synthesis, biopharmaceutical characterization, and antimicrobial study of novel azo dyes of 7-hydroxy-4-methylcoumarin," Med Chem Res, vol. 22, pp. 4202-4210, 2013.

7. H.F. Rizk, S. A. Ibrahim, M.A. El-Borai, "Synthesis, fastness properties, color assessment and antimicrobial activity of some azo reactive dyes having pyrazole moiety," Dyes and Pigments, vol. 112, pp. 86-92, 2015.

8. Ambareen Shaikh, Jyotsna S. Meshram, "Design, synthesis and pharmacological assay of novel azo derivatives of dihydropyrimidinones", Cogent Chemistry, vol.1 pp. 1-9, 2015.

9. N. Nishat, Rahisuddin, M. M. Haq, Vikrant Kumar, "Synthesis,characterization and antimicrobial activity studies of $\mathrm{N}-\mathrm{N}^{\prime}$-tetracarboxydiethyloxamide ligand and its metal(II) complexes," Journal of Coordination Chemistry, vol.59, no.15, pp. 1729-1738, 2006

10. S. Bal et al., "Synthesis, thermal stability, electronic features, and antimicrobial activity of phenolic azo dyes and their $\mathrm{Ni}(\mathrm{II})$ and $\mathrm{Cu}(\mathrm{II})$ complexes," Chemical Papers, vol.68, no.3, pp. 352-361, 2014.

11. H. Khanmohammadi et al., "Azo-azomethine dyes with N, O, S donor set of atoms and their $\mathrm{Ni(II)}$ complexes: Synthesis, characterization and spectral properties," Dyes and Pigments, vol. 98, pp. 557-564, 2013.

12. Yong-Feng Qiao, Lin Du, Jie Zhou, Yan Hu, Lin Li, Bin Li \& Qi-Hua Zhao, "Synthesis, structures, and fluorescent properties of azo anthranilic acid and its $\mathrm{Cu}(\mathrm{II}), \mathrm{Co}(\mathrm{II})$, and $\mathrm{Ni}(\mathrm{II})$ complexes," Journal of Coordination Chemistry, vol. 67 no.15, pp. 2615-2629, 2014.

13. M. E- Moustafa, S.A.Shama, "Metal Chelates of Cerium (III), Thorium(IV) and Dioxouranium(VI) with Some Heterocyclic AZO Dyes; Potentiometric and Spectrophotometric Studies," Analytical Letters, vol. 33, no. 8, pp. 1635-1644, 2000.

14. C. Anitha, S. Sumathi, P. Tharmaraj, C. D. Sheela, "Synthesis, Characterization, and Biological Activity of Some Transition Metal Complexes Derived from Novel Hydrazone Azo Schiff Base Ligand," International Journal of Inorganic Chemistry, Volume 2011, Article ID 493942, pp. 1-8, doi:10.1155/2011/493942. 
15. Ming Chen, et al., "Towards polynuclear metal complexes with enhanced bioactivities: Synthesis, crystal structures and DNA cleaving activities of CuII, NiII, ZnII, CoII and MnII complexes derived from 4-carboxy-1-(4carboxybenzyl) pyridinium bromide," Inorganica Chimica Acta, vol.405, pp. 461-469, 2013.

16. Chellaian Justin Dhanaraj, Jijo Johnson, Jeyasekaran Joseph, Raphael Selwin Joseyphus, "Quinoxaline-based Schiff base transition metal complexes: review," Journal of Coordination Chemistry. vol. 66, no. 8 pp. 1416-1450, 2013.

17. Fangfei Li, J. Grant Collins, F. Richard Keene, "Ruthenium complexes as antimicrobial agents," Chem. Soc. Rev, vol. 44, pp. 2529-2542, 2015.

18. Chung-Hang Leung, Sheng Lin, Hai-Jing Zhonga, Dik-Lung Ma, "Metal complexes as potential modulators of inflamatory and autoimmune responses," Chem. Sci., vol. 6, no.2, pp. 871-884, 2015.

19. J. R. Anacona, Maried Lopez, "Mixed-Ligand Nickel(II) Complexes Containing Sulfathiazole and Cephalosporin Antibiotics: Synthesis, Characterization, and Antibacterial Activity," International Journal of Inorganic Chemistry, Vol.2012, Article ID 106187.

20. M. Rakowski Dubois, "Catalytic Applications of Transition-Metal Complexes with Sulfide Ligands," Chemical Reviews, vol. 89, no.1, pp. 1-9, 1989.

21. S. Krompiec et al., "Transition metal compounds and complexes as catalysts in synthesis of acetals and orthoesters: Theoretical, mechanistic and practical aspects," Coordination Chemistry Reviews, vol. 256, pp. 20572095,2012

22. Marius Majewsky, et al., "Antibacterial Activity of Sulfamethoxazole Transformation Products (TPs): General Relevance for Sulfonamide TPs Modified at the para Position," Chem. Res. Toxicol, vol. 27, no. 10, pp. 1821$1828,2014$.

23. Jagdish Badgujar, Dhananjay More, Jyotsna Meshram, "Enhancement of the Antimicrobial Properties of SAP Using Beta-Cyclodextrin as an Encapsulation Agent," American Journal of Advanced Drug Delivery, vol. 4 pp. 32-44, 2016.

24. Walaa H. Mahmoud, M. M. Omar, Fatma N. Sayed, "Synthesis, spectral characterization, thermal, anticancer and antimicrobial studies of bidentate azo dye metal complexes," J Therm Anal Calorim, vol. 124, no. 2 pp. 1071-1089, 2016.

25. Roy, C. B., \& Meshram, J. S., "Dendrimeric tweezers for recognition of fluorogenic Co $2+, \mathrm{Mg} 2+$ and chromogenic Fe 2+," Journal of Luminescence, vol. 171, pp. 208-214, 2016.

26. Hoda El-Ghamry, Rehab El-Sharkawy, Mohamed Gaber, "Synthesis, structural, spectroscopic, biological and catalytic activity of $\mathrm{Co}(\mathrm{II}), \mathrm{Ni}(\mathrm{II})$ and $\mathrm{Cu}(\mathrm{II})$ complexes of benzilic hydrazide (BH), " J iran chem soc, vol. 11, pp. 379-389, 2014.

27. Mohanram I, Meshram J., "Design, synthesis, and evaluation of isoniazid derivatives acting as potent antiinflammatory and anthelmintic agents via Betti reaction," Medicinal Chemistry Research, vol. 1 no. 23(2), pp 939-47, 2014.

28. A. K. Sadana, Y. Mirza, K. R. Aneja, O. Prakash, "Hypervalent iodine mediated synthesis of 1-aryl/hetryl1,2,4-triazolo[ 4,3-a] pyridines and 1-aryl/hetryl 5-methyl-1,2,4-triazolo[ 4,3-a]quinolines as antibacterial agent," European Journal of Medicinal Chemistry, vol. 38, no. 5, pp 533-536, 2003.

29. M. O. Agwara, et al., "Synthesis, characterization and antimicrobial activities of cobalt(II), copper(II) and zinc(II) mixed-ligand complexes containing 1,10-phenanthroline and 2,2 -bipyridine," Bulletin of the Chemical Society of Ethiopia,. Vol. 24, no.3, pp. 383-389, 2010. 